See discussions, stats, and author profiles for this publication at: https://www.researchgate.net/publication/249010146

\title{
Developing sustainability in global manufacturing networks: The role of site competence on sustainability performance
}

Article in International Journal of Production Economics · January 2014

DOI: 10.1016/j.jpe.2013.06.010

\section{CITATIONS}

53

3 authors:

Ruggero Golini

University of Bergamo

59 PUBLICATIONS 779 CITATIONS

SEE PROFILE

Raffaella Cagliano

Politecnico di Milano

71 PUBLICATIONS 1,639 CITATIONS

SEE PROFILE

Some of the authors of this publication are also working on these related projects:

Global value chains and industrial clusters View project

Project Innovating Production and Sourcing Practices for Sustainability View project
Annachiara Longoni

Universitat Ramon Llull

37 PUBLICATIONS 434 CITATIONS

SEE PROFILE 


\title{
Developing sustainability in global manufacturing networks: the role of site competence on sustainability performance
}

Ruggero Golini

Università degli Studi di Bergamo

Department of Economics and Technology Management

Annachiara Longoni

Politecnico di Milano

Department of Management, Economics and Industrial Engineering

Raffaella Cagliano

Politecnico di Milano

Department of Management, Economics and Industrial Engineering

PLEASE CITE AS: Golini, R., Longoni, A., Cagliano, R., 2014.

Developing sustainability in global manufacturing networks: the role of site competence on sustainability performance. International Journal of Production Economics 147, Part B, 448-459.

doi:10.1016/j.ijpe.2013.06.010

\begin{abstract}
Environmental and social sustainability are becoming sources of competitive advantage for multinational companies. Consequently, they need to understand how to manage their global manufacturing networks to enhance both environmental and social performance. Results from an international survey show that site competence - that is having competences in operations beyond the production activities - is an antecedent of the adoption of environmental and social sustainability programs and, in turn, of higher performance improvement. Moreover, site competence provides also a direct contribution to performance achievement especially to pursue social sustainability.
\end{abstract}

Keywords: Global manufacturing networks; environmental and social sustainability; site competence 


\section{Introduction}

Given the emergence of a new economic order, companies worldwide realized that it is not enough to be successful in business, but they should also safeguard the environment, the safety and welfare of current and future generations, being committed to sustainability (Gunasekaran \& Spalanzani, 2011). Accordingly, sustainability is discussed globally by policy makers, practitioners, media and academics (Etsy \& Winston, 2009). The interrelationships among society, environment and economic development are the three "pillars" of sustainability (Elkington, 1994). Specifically, the economic dimension of sustainability is defined as having the ability to generate enough cash flow to ensure liquidity and produce a persistent return for the long term (Steurer and Konrad, 2009; Vachon and Mao, 2008); environmental sustainability is obtained if a company consumes natural resources at a slower pace than the natural regeneration and generates limited emissions and waste (Vachon and Mao, 2008); social sustainability is obtained when the organisation actively supports the preservation and creation of skills as well as the capabilities of current and future generations, and promotes health and support equal and democratic treatments within and outside its borders (McKenzie, 2004).

A key role in fostering a global sustainable development is acknowledged to multinational manufacturing firms, characterized by global manufacturing networks composed by plants located in different areas of the world (UNCTAD, 2010; Albino et al., 2009; Epstein \& Roy, 2007). Multinational companies are recognized to adopt and diffuse more easily best practices in their global manufacturing networks thanks to the presence of centers of excellence, shared knowledge and information (e.g., Martin \& Beaumont, 1998). Multinational companies such as Nike, P\&G, Nissan Motors Co. - to cite some well know examples among the others - started sustainability development from reputational crisis in a plant of their manufacturing network or from company's ambition and culture, but then achieved sustainability in the whole network and gained competitive advantage through it (Mohrman \& Worley, 2010). This result was possible thanks to shared knowledge and skills in all plants of the network that allowed to deploy sustainability at the global level. As some authors suggest (e.g., Ageron et al., 2011), environmental and social sustainability should be integrated and diffused in such global 
manufacturing networks, as happened in the past with other practices like agile manufacturing, lean production and business process reengineering (Gunasekaran \& Spalanzani, 2011).

However, such "success stories" should not overshadow reality. Lots of companies experience difficulties in spreading sustainability within their global manufacturing networks (Dyllick \& Hockerts, 2002). In the past, for example, companies offshored their activities mainly seeking low cost of work (e.g., Kinkel and Maloca, 2009), often locating plants where environmental and social regulations are lacking or not enforced (Jahns et al., 2006). Turning these plants into sustainable manufacturing locations is a hard task, and even if global manufacturers are introducing programs oriented to control and improve their sustainability practices along the entire network (e.g., Rao, 2002), not all plants achieve the same results (Christman, 2000; Angell \& Klassen, 1999; Zhu \& Sarkis, 2004).

Interestingly, this is not only an issue for plats in developing countries. In these countries, instead, some plants are able to leapfrog to good sustainability performance since they start from the green-field, while plants in developed countries sometimes struggle to be compliant with regulations because of the old technologies in place. In conclusion, the way in which different plants in global manufacturing networks can actually pursue and achieve sustainability is still an open and relevant issue (Klassen, 2001). The main gap in the literature is related to understanding how multinational companies can spread effectively the corporate sustainability orientation among the different plants of the network and which could be the pre-requisites and drivers (Albino et al., 2009).

According to the literature, the challenge of sustainability requires companies to develop new tools, new skills and new programs based on highly specific expertise available at the plant level (Albino et al., 2009). The literature uses the concept of site competence, defined as the number of processes the plant is responsible for, to represent such expertise (Ferdows, 1997; Vereecke \& Van Dierdonck,2002).

Site competence is one of the key elements to describe a global manufacturing network strategy, since plants can play different roles according to the level of site competence - from just producing the product as mandated by the headquarters, to designing the products and being a center of excellence for the entire network (Ferdows, 1997). 
In line with the Resource Based View (RBV) of firms, literature suggests that the presence and internal integration of higher organizational capabilities related to internal and external organizational skills, resources, and functional competences developed within firms (Bowen et al., 2001; Lee \& Klassen, 2008; Peteraf, 1993; Teece et al., 1997) might have an increasingly important role in developing social and environmental sustainability (Hart 1995; Christmann, 2000). These capabilities allow to develop complex sustainability strategies by sharing knowledge and integrating different operations activities (i.e., product design, production, procurement and distribution) (e.g., Gunasekaran \& Spalanzani, 2011).

In line with these reasoning, we propose that the level of site competence, defined according to Ferdows (1997), is a key element to understand how to deploy environmental and social sustainability performance in global manufacturing networks.

However, the site competence in global manufacturing networks has never been explicitly put in relation with environmental and social sustainability. This paper aims to fill this gap looking at environmental and social sustainability from a plant-level perspective. We deliberately did not include the economic dimension of sustainability (the so-called third pillar) because literature suggests that it lies on a different level, being simultaneously an enabler and a final goal (e.g., Morrison-Saunders \& Therivel, 2006).

More in detail we would like to understand if different levels of site competence can have a twofold effect: i) directly creating environmental and social sustainability capabilities; and ii) leading to higher adoption of environmental and social sustainability related action programs, thus fostering sustainability performance.

In the following paragraphs we review the literature on global manufacturing networks and sustainability, subsequently we provide details about the methodology used and finally we present and discuss results.

\section{Literature review}

\subsection{Global manufacturing networks and site competence}

One of the most recent research trajectories in Operations and Supply Chain Management literature considers the role of manufacturing and supply chain systems in a global environment thus analyzing how companies manage operations activities distributed all over the world and the related processes (e.g., MacCarthy and 
Atthirawong, 2003). In fact, more and more companies have extended their manufacturing network outside the national borders.

While past research on multi-plant organizations focused mainly on localization decisions (Shi and Gregory, 1998; Meijboom and Voordijk, 2003), with the main driving variable being cost (Schmenner, 1979), more recently scholars recognized the need to include a number of different strategic variables to explain how a global manufacturing network is designed and developed.

In particular, one of the most established ways to look at the strategies in managing global manufacturing networks is to consider the "role of the plant", that combines the localization advantage for establishing a foreign factory (e.g., low cost resources, proximity to market, access to skills and technology, proximity to suppliers, sociopolitical and competition factors (see Ferdows, 1997; Vereecke \& Van Dierdonck, 2002); with the level of site competence, that can range from just producing the product as mandated by the headquarters to design the products and be a center of excellence for the entire network (e.g., Ferdows, 1997).

The latter concept has been proposed first by Ferdows in his 1989 paper. Site competence was defined as the breath of technical activities carried out at the site. In his more recent work (Ferdows, 1997), Ferdows defines the competence as the extent to which the activities performed by the plant go beyond simply producing the goods, for example, process engineering and improvement, product customization, after-sales service, decision making on procurement and distribution, and, ultimately, product development and being a center of excellence for the entire network.

In particular, Ferdows $(1989,1997)$ developed a classification of plants in global manufacturing networks that distinguishes plants on the basis of location advantages and the level of site competence, and identifies six types of plants: offshore, source, server, contributor, outpost, and lead plant. Ferdows's model gained academic recognition and many researchers have taken it as a starting point for their research (Vereecke and Van Dierdonck, 2002; Fusco and Spring, 2003; Meijboom and Voordijk, 2003; Meijboom and Vos, 2004; Maritan et al., 2004; Cheng at al., 2011).

Therefore the level of site competence has been more and more related to the development of organizational capabilities (e.g., Cheng et al., 2011), showing how plants with different site competence levels play a different role in fostering such capabilities and how they can be used to develop and transfer best practices within the 
global manufacturing network, as done also for lean production and business process reengineering (Gunasekaran \& Spalanzani, 2011). Accordingly, a source plant mainly serves as a receiver, copying the manufacturing process from the contributor and pilot plants (Cheng et al., 2011).

\subsection{The link between site competence and sustainability: research hypotheses}

Literature adopting the resource-based view (RBV) of the firm suggests that organizational capabilities play a major role in the sustainability strategies of the firms and impact their sustainability performance (e.g., Christmann, 2000; Dowell et al., 2000; Hart, 1995). Achieving results on the three dimensions of the bottom line requires to balance actions between long and short-term strategies and among influential stakeholders (Roberts, 1992; Pirsch et al., 2007) and is far beyond implementing different sustainability programs (Mohrman \& Worley, 2010). It requires to develop the capabilities to change traditional manufacturing networks designed to achieve financial outcomes into manufacturing networks that are able to achieve the complex set of sustainability outcomes. This shift requires to develop new capabilities throughout the global manufacturing network.

In addition, in designing sustainable manufacturing networks, a key issue is the availability of plants' capabilities of design, manufacturing, assembly, procurement and distribution (Melo et al., 2009), since sustainability can be deployed in all this processes (Sarkis et al., 2010).

As a consequence, we believe that site competence is a key driver to explain sustainability performance in global manufacturing networks.

Therefore we posit the following hypothesis:

HP1: Higher levels of site competence are positively related to environmental and social performance.

This positive relation might be due to both a direct effect of site competence on environmental and social sustainability performance and an indirect effect mediated by the adoption of environmental and social programs.

The direct effect of site competence is due to the fact that environmental and social sustainability are fostered by cross-functional integration (Christman, 2000) and by 
innovating all the different stages of the manufacturing process, from product/process design, to production, to distribution. Indeed plant sustainability is developed in each of these operations activities (Gunasekaran \& Spalanzani, 2011):

i) in product/process design and development, determining sustainable product and process design and development strategies, techniques and tools (e.g., Zhu et al., 2005; Chung \& Wee, 2008);

ii) in production operations, managing the processes with sustainable inputs such as energy, people, equipment and machines with the objective of reducing waste, rework, inventory and delays as well as reducing carbon footprint and preserving and increasing working conditions (e.g., Zhu \& Sarkis, 2004; Baldwin et al., 2005; Zhu et al., 2005; Zhu et al., 2007; Lee \& Kim, 2009; Andersen \& Skjoett-Larsen, 2009);

iii) in procurement operations, including upstream supply chain management which involves make or buy decisions, supplier selection, purchasing or procurement and outsourcing according to sustainability principles (Zhu \& Cote, 2004; Zhu et al., 2005; Vachon \& Mao, 2006; Vachon \& Mao, 2008; Pagell \& Wu (2009);

iv) in distribution chain operations, effectively designing and managing their logistics resources to mitigate negative environmental and social impact (Sarkis, 2003; Pagell et al., 2004; Ravi et al., 2005; Zhu et al., 2005; Sheu et al., 2005; Vachon \& Mao, 2006).

In this context, high levels of site competence - that comprise the ability of integrating and sharing knowledge concerning product/process engineering and improvement, manufacturing, decision making on procurement and distribution (Ferdows, 1997) - might play a relevant role in achieving environmental and social sustainability.

Therefore this sub-hypothesis has been formulated:

HP1.1: Higher levels of site competence have a positive, direct impact on environmental and social performance.

All the same, site competence can be considered an antecedent of environmental and social programs adoption. Literature widely recognized the impact of environmental and social programs to achieve sustainability performance (e.g., Klassen \& Whybark, 2007; Sarkis et al., 2010; Klassen \& Vachon 2003) suggesting that when plants adopt such programs, they are the actual responsible of sustainability achievement. Anyway, previous research suggests that even though firms are more and more aware of the 
global sustainability challenge, this does not always result in investing more time and money in sustainability programs (Cordeiro \& Sarkis 1997, Aragon-Correa \& RubioLopez 2007).

Until now, limited research in Operations and Supply Chain Management has investigated the factors that enable or drive sustainability programs adoption (Ates et al., 2012). Besides the role played be a number of contingencies, literature suggests that internal resources and firm's capabilities, such as site competence, help explain differences in firm's sustainability programs adoption and consequently performance achievement (Lee \& Rhee, 2007; Sarkis et al., 2010). Literature discusses two main reasons to explain the relationship between site competence and environmental and social sustainability programs. First of all, where a plant has failed to develop site competence and it is not competitive (e.g., Vereecke \& Van Dierdonck, 2002), it might divert managerial attention and investment away from areas that might be perceived as peripheral, such as potentially environmental and sustainability programs (Klassen, 2001) to focus on traditional competitive issues, such as cost, time, quality and flexibility. So, when site competence is low, we can expect that the plant adopts sustainability programs to a lower extent. On the contrary, when site competence is well developed it might be possible that the plant invests more on such programs.

Second, the adoption of environmental and social programs is complex (AragonCorrea, 1998; Hart, 1995; Carter, 2005; Pullman et al., 2009). Mohrman \& Worley (2010) highlight that sustainability programs implementation is more than just a technical process and requires instead the redesign of organizations according to organizational capabilities. The literature also suggests that companies are quite aware of these difficulties and operations managers realize that they should avoid complex sustainability strategies when they do not have the capabilities to manage them (Aragon-Correa, 1998; Hart, 1995). On the contrary, managers in organizations with greater capabilities adopt more easily environmental and social programs (Russo \& Fouts, 1997).

Thus we state the next sub-hypothesis:

HP1.2: Site competence, as antecedent of environmental and programs adoption, has a positive, indirect impact on environmental and social performance.

Figure 1 describes the general research model summarizing the research hypotheses. 


\section{FIGURE 1 ABOUT HERE}

To provide empirical evidence to such hypothesis, we analyzed the impact on the overall sustainability considering environmental and social sustainability as a whole concept (environmental and social programs adoption at the same time and environmental and social performance achievement at the same time), but also showing the impact on environmental issues (environmental programs adoption and environmental performance achievement) and social issues (social programs adoption and social performance achievement) separately.

\section{Methodology and measures}

To investigate our research hypotheses, we have used data collected from the fifth edition of the International Manufacturing Strategy Survey (IMSS 5), a research project carried out in 2009 by a global network. This project, originally launched in 1992 by the London Business School and Chalmers University of Technology, studies manufacturing and supply chain strategies within the assembly industry (ISIC 28-35 classification) by simultaneously administering a detailed questionnaire in many countries through local research groups. The basic structure of the questionnaire remained quite similar over time such that the last editions can contain robust core constructs. Moreover, the questionnaire and all the studies based on it (as well as our), are designed keeping on the background the same framework, that fundamentally is the causal chain: objectives - action programs - performance improvement. In addition, for each edition, the questionnaire is partially redesigned by an international team to ensure its alignment with the most recent research goals. This update is carried out by a design team composed of a pool of international researchers and, thus, avoids the researchers' country-biases (Van de Vijver and Leung, 1997).

The companies are sampled randomly or by convenience. When using convenience sampling, the selection is purposefully biased towards excellent, best practice companies within each country. This means that the companies in the sample will be the most known, the best performing ones (e.g., on profit), the ones that have more international visibility, the ones that are more representative of the specificities and strengths of the country. In this way the final sample is composed by a wide set of 
companies financially stable and that adopt a variety of advanced manufacturing practices (http:// www.manufacturingstrategy.net). The appropriateness of this sampling strategy and of IMSS measures is supported by the many papers published from different IMSS rounds to study manufacturing strategies (e.g., Frohlich and Westbrook, 2001; Gimenez et al., 2012; Voss and Blackmon, 1998).

The target respondent to the questionnaire is a plant, production or operations manager. Every research group performs pilot tests of the survey with managers and statistical tests (late and non-respondent bias) to ensure the validity of the questionnaire ad of the sample. Following the suggestion of the literature (Chang et al.; Malhotra et al., 2006; Podsakoff et al., 2003), anonymity and confidentiality were guaranteed to the respondents. Moreover, the questions are clear and concise. Next, the adoption of best practices is asked in different sections of the questionnaire and separately from competitive priorities. In gathering data, partners follow the same procedure ${ }^{1}$ and use the same questionnaire ${ }^{2}$. Finally responses are gathered in a unique global database. The sample consists of 725 firms from 21 countries, with a response rate of $16.3 \%$.

For the purposes of this study, 534 companies provided the required information. We checked any potential bias introduced by this reduction of the sample. Data show that there are no significant differences in terms of country, size, industry and business performance between the companies excluded and the ones included in the analyses. The distribution of the sample in terms of country, industry and size is shown in Tables $1 \mathrm{~A}$ and $1 \mathrm{~B}$.

TABLES 1A AND IB ABOUT HERE

Respondents have on average 11 years of experience in the operations and more than $85 \%$ of the companies declare to have a return of investment equal or superior to their main competitors.

\subsection{Items selection}

\footnotetext{
${ }^{1}$ If the respondent shows some interest in participating in the research, the questionnaire is sent to him/her. After some weeks, a reminder is sent if no feedback has been received. Questionnaires that are sent back are controlled for missing data and are handled case-by-case, usually by contacting the company again. We then control the gathered data for late respondent bias on company size and industry.

${ }^{2}$ The first section of the questionnaire is related to the business unit and gathers general information (e.g., size, industry, and production network) on the context in which manufacturing takes place, but the other sections refer to the dominant activities of the plant and focus on business and manufacturing strategies, practices and performances. Dominant activities refer to the most widely diffused and relevant method of operation, which is considered to best represent the plant itself. The plant is chosen as the unit of analysis to avoid the problems related to business units with multiple plants operating in different ways.
} 


\section{Control variables}

According to the literature, we have considered five control variables in our analysis. One of the most important control variables considered by the OM literature with respect to sustainability is company size (e.g., Vachon, 2007). In our analyses, company size is measured through the logarithm of the number of employees of the business unit, as is frequently done. The host country of the company is another important factor to be included. Since there is evidence in the literature that companies in developed countries tend to have higher adoption of sustainability programs (e.g., Law \& Gunasekaran, 2012) we included the GNI per capita (2008, Atlas Method) of the country the plant belongs to as a control variable.

The extent to which the company considers sustainability a competitive priority is a third relevant factor affecting environmental and social sustainability performance (Porter \& Kramer 2006; Gimenez et al., 1012). We labeled this variable sustainability orientation and we have two separate measures, one for environmental sustainability measured though the priority given to environmentally sound products and processes, and social sustainability, measured through the priority given to committed social responsibility. Both items are measured on a 1-5 Likert scale (1: not important; 5: very important). Finally, delocalized plants have been suggested to achieve different levels of environmental and social sustainability performance since sustainability programs are often developed and spread from the headquarters to the other plants in the network (Kassinis \& Vafeas, 2002). As a consequence, we have introduced home country, that is a binary control variable that says whether the surveyed plant is in its home country or if the headquarters are in another country.

\section{Site competence}

Site competence is measured consistently with the scales developed by Vereecke and Van Dierdonck (2002). The respondent has to classify the strategic role of his/her plant into one of the following five categories:

1. To get the products produced. Managerial investment in the plant is focused on running the plant efficiently.

2. To have sufficient internal capabilities to develop and improve its own components, products and production processes 
3. To develop specific important components, products or production processes, also for other plants.

4. To develop and contribute know-how for the whole company.

5. To be a "center of excellence" for building strategic capabilities in the manufacturing function.

\section{Environmental and social sustainability programs}

Sustainability programs are all measured on 1-5 Likert scales indicating the effort exerted by the company in the last three years on the program (1: no effort; 5 : high effort). We have included the following programs in our analysis. For environmental sustainability: environmental-friendly product design (e.g., eco-design, design for environment, and life cycle assessment) (Zhu \& Sarkis, 2004); environmental process management (e.g., environmental management standards such as ISO14001, quality management standards, and total quality environmental management) (Daily \& Huang, 2001); environmental logistics policy (e.g., environmental transportation, packaging, warehousing, and reverse logistics) (Ciliberti et al., 2008).

For social sustainability we have included the following items: internal social programs (e.g., employment, safety, work conditions, corporate social activities, support community projects) (Zairi \& Peters, 2002); supply chain social programs (Carter, 2005). Table 2 summarizes the programs included in the analysis.

\section{TABLE 2 ABOUT HERE}

\section{Sustainability performance}

Performance indicators are measured in terms of the improvement of the performance over the last three years, with a 1-5 Likert scale (1: much worse; 5 : much better). We considered the following performance: environmental performance, encompassing pollution and consumption performance (e.g., Labuschagne et al. 2005; Gimenez et al. 2012); social reputation, which measures the external (community) dimension of social sustainability (e.g., McKenzie 2004); employee satisfaction, which measures the workforce dimension (e.g., McKenzie 2004).

\section{Constructs definition}


After the selection of the items, we run an exploratory factor analysis on the sustainability items (i.e. performance, programs and orientation) to check for discriminant and convergent validity. The analysis shows that environmental and social aspects stay together and three constructs are identified: overall sustainability performance, overall sustainability programs and overall sustainability orientation (Table A.1 in appendix). The analysis shows good indicators in terms of factor loadings (above 0.63), Cronbach's alpha (above 0.8) and variance explained (71\%). However, when running the factor analysis separately for social sustainability and environmental sustainability, the models are still acceptable, even if less parsimonious and with several single-item measures3. In conclusion, we decided to perform three separate analyses: one using overall sustainability constructs (i.e. social and environmental together) and two using social and environmental sustainability constructs. In this way, we have a more aggregate and robust result (using the overall constructs), but we can also check whether the results hold when considering social and environmental aspects separately. Table A.2 and A.3 reports descriptive statistics and correlations among the identified constructs.

\subsection{Data analysis}

First of all, we assessed that common method bias does not affect our data significantly. The questionnaire is already designed to minimize Common Method Bias issues that might occur in survey-based studies with single respondents and perceptive scales. Common Method Bias can affect statistical results by inducing correlations or social desirability. Following the suggestions of the literature (Chang et al., 2010; Malhotra and Sharma, 2008; Podsakoff et al., 2003), we guaranteed anonymity and confidentiality to the respondents. Moreover, the questions are clear and concise. Finally, the adoption of best practices are asked in different sections of the questionnaire, and these practices are separated from competitive priorities and

\footnotetext{
${ }^{3}$ Environmental programs (3 items): factor scores above 0.8 , Cronbach's alpha above 0.8 Environmental performance: single item Environmental orientation: single item Variance explained above $85 \%$

Social programs (2 items): factor scores above 0.8 , inter-item correlation $=0.483$ (sig. 0.000 ) Social performance $(2$ items): factor scores above 0.8 , inter-item correlation $=0.628$ (sig. 0.000$)$ Social orientation: single item Variance explained above $84 \%$
} 
performances. We also checked ex-post that Common Method Bias does not represent a significant problem with our data, using the Harman's one single factor test (Podsakoff et al., 2003): one single factor accounts for less than $40 \%$ of the total variability of the variables in the analysis.

In order to test our research hypotheses some preliminary analyses have been performed to show the pattern of sustainability programs and performance in relation to the level of competence. This analysis allowed to split the sample in two (low and high competences). Next, hypotheses have been tested using a linear regression analysis since we hypothesized a linear relationship among the variables. This method is appropriate since performance and programs are averaged Likert scales that can be considered appropriate for parametric tests (Carifio and Perla, 2008). In particular, given our interest in studying a mediation effect, we have adopted the three steps methodology suggested by Baron and Kenny (Baron and Kenny, 1986):

1. Regress the mediator (i.e. programs) on the independent variable (i.e. competence);

2. Regress the dependent variable (i.e. performance) on the independent variable;

3. Regress the dependent variable on the mediator and the independent variable. In order to have a mediation effect, all the regression coefficients have to be significant except in the third regression where the effect of the independent variable has to be lower than in step 2 regression (or even null).

In doing this analysis, each step of the procedure has been also controlled for multicollinearity by checking the variance inflation factor (VIF) of the regressors. VIF is always lower than 2, whereas the cut-off point is usually between 5 or 10 (Hair et al., 1998; Menard, 2002; Neter et al., 1989). Therefore, the effect of multicollinearity on our results is very low. Standardized variables have been employed to ensure that differences in scale among the variables do not affect the results and to increase the interpretability of the regression terms. We have also checked the normality and independence of the residuals. Furthermore we have controlled that there is nonnegative relationship between sustainability programs and business performance (measured through the Return On Investment relative to competitors and Return On Investment improvement in the last three years). Given a positive correlation between sustainability investments (and performance) and business performance, we can exclude 
that, in our dataset, companies that invested in sustainability worsened their business performance.

\section{Results}

Table 3 represents the distribution of our sample according to the level of site competence and the location in the home country or in another country. We can observe that the sample is quite well distributed among the different categories, with a prevalence of companies with relatively low competence and operating in their home country. It is particularly interesting to notice that there is no relationship between the site competence and the home country (chi-square test is not significant). This means that companies in the home country do not necessarily have higher competence compared to delocalized plants.

\section{TABLE 3 ABOUT HERE}

Table 4 shows the average values of programs and performance for the companies belonging to the different Competence Groups (CG). It is possible to observe that, on average, the higher the competence the higher the adoption of sustainability programs and performance achieved. We have also performed a t-test to check whether one group is significantly different from the previous one. On the overall sustainability variables (i.e. social and environmental), plants in the CG-2 have a significantly higher adoption of programs and level performance compared to those in CG-1. Similarly, companies in CG-4 tend to have higher values than companies in CG-3. The same behavior can be observed if we split the overall sustainability into the social and environmental components. The only difference is on environmental programs: there is no significant difference between companies in CG-4 and CG-3, but CG-5 has higher adoption of programs than CG-4.

\section{TABLE 4 ABOUT HERE}

As mentioned in the Data Analysis section, the above results allowed us to group companies in two: low competence (LC) and high competence (HC). In this way, site competence becomes a dummy variable (ComptenceHL). 
Based on this new variable, hypotheses have been tested through a three-step methodology, controlling for the GNI of the country, the strategic orientation to sustainability, the size and the localization in the home country.

The results of the first step of the regression show that there is a significant effect of competence over programs adoption (Table 6). The analysis has been run also for social and environmental programs separately and the results are the same.

\section{TABLE 6 ABOUT HERE}

In the next step, we tested the direct relationship between site competence and sustainability performance without (model 1) and with (model 2) the mediator variable (i.e., sustainability programs).

Table 7 shows that moving from model 1 to model 2 the coefficient of CompetenceHL and its significance level decrease. This result is the same for the overall sustainability model and when social and environmental sustainability are considered separately. However, for the social model, the drop in the significance is not very strong thus, in model 2 , CompetenceHL remains significant at $5 \%$. In the environmental and overall sustainability models, instead, the drop is stronger and, in model 2, the significance of CompetenceHL is higher than 5\%, but still lower than $10 \%$, highlighting a weak, but significant, effect.

\section{TABLE 7 ABOUT HERE}

\section{Discussion}

The analyses performed allow to test the hypotheses formulated and thus to better understand the role of site competence to achieve sustainability in global manufacturing networks.

HP1.1 Direct Positive relation between site competence and sustainability performance 
The first regression model (Table 7 - Model 1), that tests the direct impact of site competence on environmental and social sustainability performance (as an overall concept and separated), confirms the positive relationship between the two variables. In particular, a higher site competence corresponds to higher environmental and social performance improvement. This means that in order to achieve higher environmental and social performance it is important to develop cross-functional and integrated competence at the plant level (Christman, 2000; Daily \& Huang, 2001). Referring to the entire manufacturing network, this result means that managers should expect higher achievements in terms of environmental and social performance from those plants that have more competences. On the contrary, plants that are focused only on production will achieve only incremental sustainability improvements. Interestingly, the home country variable is never significant, meaning that any plant in the network can be outperforming, if it has the necessary competence.

As a matter of fact, the presence of multiple competences inside the plant favors the intra- and inter-organizational communication and fosters the creation of a learning organization more open and sensitive to environmental and social sustainability issues (Edwards, 2009).Such capabilities are critical to develop complex strategies related to both environmental and social issues (Mohrman \& Worley, 2010; Seuring \& Muller, 2008), but also to achieve social and environmental performance separately. In fact, the positive relationship between site competence and sustainability performance is confirmed even when social and environmental performance are considered separately showing that for both dimensions site competence is an enabling factor.

As suggested by the literature (e.g, Gunasekaran \& Spalanzani, 2011), all the stages of the operations activities - product/process design, production and distribution impact on environmental issues. As a consequence, enhancing environmental performance requires the definition of cross-functional solutions thanks to integrated knowledge and the ability to share ideas within the organization (De Brito et al., 2008; Rothenberg, 2003). The same goes for social sustainability issues that have to be considered in each operations activity and that need cross-functional knowledge creation and diffusion to be pursued.

HP1.2 Site competence, as antecedent of sustainability programs, positively impacts on sustainability performance. 
Our analyses of the relation between site competence and sustainability programs adoption (Table 6 and Table 4) show that plants with higher competence have higher adoption of sustainability programs, in line with the literature (Bonifant et al. 1995; Hart, 1995). Site competence provides the capabilities to manage complex environmental and social sustainability programs (Aragon-Correa, 1998). Especially environmental sustainability programs are cross-functional and need integrated skills to be effectively adopted (Daily \& Huang, 2001; Govindarajulu \& Daily, 2004). Because of that, integrated site competence, regarding product/process design, procurement, production and distribution provides the capabilities for an extensive adoption.

Moreover, plants that have high site competence are recognized to be "center of excellence" for building strategic capabilities in the manufacturing function, thus providing a competitive hedge for the entire network. From this standpoint, managers of plants that are "centers of excellence" should develop environmental and social programs as a way to create competitive advantage for the entire company, by increasing corporate image and reputation (Brown \& Dacin, 1997; Maignan \& Ferrell, 2004), by allowing cost reduction and efficiency gains (Pagell et al., 2004), and, finally, by fostering product of process innovation (Porter \& Van de Linde, 1995). Furthermore, social and environmental programs are expensive (Gimenez et al., 2012) and only plants with high competence decide to adopt them because they see opportunities to enhance their competitive advantage, and, whether possible, get some cost savings at the same time (e.g., Pagell et al., 2004). Considering the whole global manufacturing network, this result shows that only plants with a broad competence can extensively adopt sustainability programs, especially those that involve product design or the interaction with supply chain partners. Vice versa, plants with restricted competence can experience difficulties in adopting and spreading sustainability programs beyond the production function.

This result holds even when considering environmental and social programs separately. Both types of sustainability programs require integrated capabilities to be effectively adopted (e.g., Daily \& Huang, 2001; Stead \& Stead, 2009). For example, in relation to environmental issues, design for environment programs need design responsibility to be adopted and developed; or, in relation to social issues, monitoring sustainability performance of the suppliers requires that the plant has some degree of 
responsibility over the supplier selection and monitoring processes and the capabilities to do that.

Moreover the test of the mediation effect (Table 7) shows that the significance of site competence on performance drops in favour of the role of sustainability programs. Specifically, there is a partial mediation effect in all models. Specifically, in the mediation model regarding social programs and performance, the site competence reduces its significance and coefficient, but remains significant at 5\%. Therefore, in the social model even if social sustainability programs account for the largest explaining power over the performance, site competence still plays a direct role on performance. Instead, in the mediation model regarding environmental programs and performance and in the mediation model regarding overall sustainability (environmental and social at the same time), there is partial mediation even if the significance of the direct link is not so strong as in the social model. In these cases, environmental programs and overall sustainability programs have the most relevant effect on performance, but the direct effect of site competence is still needed to fully achieve sustainability.

\section{Overall research model}

To conclude, evidence suggests that the role of site competence is twofold. In particular, higher environmental and social sustainability performance is achieved thanks both to a direct effect of site competence and to an indirect effect of site competence that favors and enhance the adoption of sustainability programs (AragonCorrea, 1998; Christman, 2000).

This is in line to what suggested by Mohrman \& Worley (2010). Site competence allows to deploy sustainability strategies as a different way to operate in different operational process and not just to implement new sustainable technologies, certifications and programs not integrated with the operations systems. Moreover, sustainability challenges are continuously evolving and emerging (e.g., Russo, 2009; Mohrman \& Worley, 2010; van Kleefe \& Roome, 2007) and thus companies need to continuously find innovative solutions to manage sustainability issues. An high level of site competence might provide the capabilities needed to continuously develop plant's competitiveness. 
As mentioned before, the direct effect of site competence is particularly significant for the social model (partial mediation). In this case, site competence is not only the antecedent of social programs adoption, but has also a significant impact on social performance (e.g., in keeping more skilled and satisfied workers or provide the responsibilities to manage in a responsible way all operations activities).

On the other side, in the environmental model, site competence is relevant especially to support environmental programs adoption; this can be explained by the importance of site competence in fostering the adoption of complex technologies and practices related to pollution or consumption reduction issues (Klassen \& Whybark, 2007; Klassen, 2001) that are crucial for environmental sustainability.

A possible explanation of the higher significance of the mediation effect of environmental programs compared to the partial mediation of social programs might be that environmental programs are nowadays rather widespread in operations, compared to social sustainability strategies (e.g., Kleindorferer et al., 2005). Thus, the achievement of higher social sustainability performance does not only go through the implementation of specific programs, but also through the day by day responsible management of operations, that requires more organizational adaptability, skills and capabilities.

In conclusion, from the global manufacturing network perspective, this result provides a final confirmation that in order to increase sustainability performance it is not only necessary to push the adoption of some programs from the headquarters to the subsidiaries, but it is also necessary to increase the level of competence inside the network.

\section{Conclusions}

Sustainability is globally emerging as a source of competitive advantage or, when ignored, of reputational disaster (Darnall et al., 2008). Operations management and supply chain management literature is recognizing the need to consider such issue in supply chain systems management, and more specifically in manufacturing networks (Van Bommel, 2011). Sustainability development is extremely complex, especially when considering environmental and social issues at the same time (e.g., Russo, 2009; Mohrman \& Worley, 2010). Moreover, specific guidance on how to develop sustainability effectively, especially in a global context, is still missing. Even if 
multinational companies are investing more and more on sustainable strategies (Albino et al., 2009), plants within the network are achieving different results. This research sheds some light on how to deploy sustainable strategies along the manufacturing network of multinational companies focusing on the role of site competence. Site competence has been shown to be related to both sustainability performance and programs adoption providing organizational capabilities to manage complex and continuously evolving sustainability issues (van Kleefe \& Roome, 2007).

This research highlights that to achieve social and environmental performance, site competence has a twofold role: it is an antecedent of the adoption of sustainability programs and it has a direct impact on performance. Site competence provides the capabilities to adopt environmentally friendly technologies and practices, and, through this, allows to obtain superior environmental performance and at the site time to deploy integrated skills allowing to achieve environmental performance enhancing synergies. Furthermore when considering social sustainability, site competence has an even higher direct effect on sustainability performance, thanks to the greater ability to keep more skilled and motivated workers and to have a more responsible management of operational activities.

We deem our results to be very relevant for research and practice. In fact, in terms of theoretical contribution, our research is twofold. It extend the existing knowledge on the development of sustainability strategies in global manufacturing networks, showing that in order to deploy environmental and social goals companies need to focus on the plants characterized by higher competence and integration among all operations processes. We empirically show how the complexity of adoption and implementation of sustainability strategies can be overcome through higher levels of site competence. In fact, higher competence refers to having responsibility on more processes and the ability to integrate and share knowledge in relation to different operations activities. This is especially true for those plants that are recognized as "centres of excellence". In addition, it extends the knowledge about the role of site competence in global manufacturing networks showing that it is related also to environmental and social sustainability performance and not with only to traditional operations performance as done so far (e.g., Chen et al., 2011; Vereecke and Van Dierdonck, 2002)

In terms of managerial contributions, our results suggest that when a multinational company is deploying a sustainable manufacturing strategy globally, it should consider 
the level of site competence to understand in which plants this will be achieved effectively. Our results suggest that the development of sustainability strategies in lowcompetence plants might be very difficult and ineffective or might be pursued only by adopting simple programs or technologies not requiring high level of competence, thus suggesting that in this kind of plants sustainability cannot be a top priority. Another possible implication is that the different plants in the network can play specific roles in the development and diffusion of sustainability. In particular, plants with high site competence can be used to develop the best sustainability practices according to companies priorities, and then these practices might be transferred to the other plants of the network, as it has been suggested in relation to traditional operational practices and capabilities (Cheng et al., 2011; Ferdows, 1997). Nevertheless since our data are crosssectional we are not able to assess empirically this assumption; therefore we suggest that this aspect might be a future development of this research.

The main limitation of this research is due to the focus on some specific industries (i.e. assembly manufacturing) and future research might be directed to prove the generalizability of results achieved. Moreover, future research might also integrate our results considering also strategic reasons for delocalization, that allow to define more precisely the role of different plants in global manufacturing network.

\section{References}

Ageron, B., Gunasekaran, Spalanzani, A., 2011. Sustainable supply management: An empirical study. International Journal of Production Economics, doi:10.1016/j.ijpe.2011.04.007.

Albino, V., Balice A., and Dangelico, R.M., 2009. Environmental Strategies and Green Product Development: an Overview on Sustainability-Driven Companies. Business Strategy and the Environment, 18, 83-96.

Andersen, M., Skjoett-Larsen, T., 2009. Corporate social responsibility in global supply chains. Supply Chain Management: An International Journal, 14 (2), 75-86.

Angell, L.C., Klassen, R.D., 1999. Integrating environmental issues into the mainstream: an agenda for research in operations management. Journal of Operations Management, 17 (1), 575-598.

Aragon-Correa, J.A., 1998. Strategic Proactivity and Firm Approach to the Natural Environment. Academy of Management Journal, 41, 5, 556-567. 
Aragon-Correa, J.A., Rubio-Lopez, E.A., 2007. Proactive corporate environmental strategies: myths and misunderstandings. Long Range Planning, 40, 357-381.

Ates, M.A., Bloemhof, J., van Raaij, E.M., Wynstra, F., 2012. Proactive environmental strategy in a supply chain context: the mediating role of investments. International Journal of Production Research, 50 (4), 1079-1095.

Baldwin, J.S., Allen, P.M., Winder, B., Ridgway, K., 2005. Modelling manufacturing evolution: thoughts on sustainable industrial development. Journal of Cleaner Production, 13, 887-902.

Baron, R.M., Kenny, D.A., 1986. The moderator-mediator variable distinction in social psychological research: Conceptual, strategic, and statistical considerations. Journal of personality and social psychology 51 (6), 1173-1182.

Bonifant, B.C., Arnold, M.B., Long, F.J., 1995. Gaining competitive advantage through environmental investments. Business Horizons, 38(4), 37-47.

Bowen, F.E., Cousins, P.D., Lamming, R.C., Farukt, A.C., 2001. The role of supply management capabilities in green supply. Production and Operations Management 10, 174-189.

Brown, T.J., Dacin, P.A., 1997. The company and the product: corporate associations and consumer product responses. Journal of Marketing, 61 (1), 68-84.

Carifio, J., Perla, R., 2008. Resolving the 50-year debate around using and misusing Likert scales. Medical Education 42 (12), 1150-1152.

Carter, C.R., 2005. Purchasing social responsibility and firm performance: The key mediating roles of organizational learning and supplier performance. International Journal of Physical Distribution \& Logistics Management, 35 (3) pp. 177 - 194

Chang, S.J., Van Witteloostuijn, A., Eden, L., 2010. From the Editors: Common method variance in international business research. Journal of International Business Studies $41(2), 178-184$.

Cheng, Y., Farooq, S., and Johansen, J., 2011). Manufacturing network evolution: a manufacturing plant Perspective. International Journal of Operations \& Production Management, 31 (12), 1311 - 1331.

Christmann, P., 2000. Effects of "Best Practices" of Environmental Management on Cost Advantage: The Role of Complementary Assets. The Academy of Management Journal, 43 (4), 663-680.

Chung, C.J., Wee, H.-M., 2008. Green-component life-cycle value on design and 
reverse manufacturing in semi-closed supply chain. International Journal of Production Economics 113, 528-545.

Ciliberti, F., Pontrandolfo, P., Scozzi, B., 2008. Logistics social responsibility: standard adoption and practices in Italian companies. International Journal of Production Economics 113, 88-106.

Cordeiro, J. and Sarkis, J., 1997. Environmental proactivism and firm performance: evidence from security analyst forecasts. Business Strategy and Environment, 6 (2), $104-114$.

Daily, B.F., Huang, S., 2001. Achieving sustainability through attention to human resource factors in environmental management. International Journal of Operations \& Production Management, 21 (12), 1539-1552.

Darnall, N., Henriques, I., Sadorsky, P., 2008. Do environmental management systems improve business performance in an international setting? Journal of International Management, 14(4), 364-376.

De Brito, M.P., Carbone, V., Blanquart, C.M., 2008. Towards a sustainable fashion retail supply chian in Europe: Organization and performance. International Journal of Production Economics, 114, 534-553.

Dowell, G., Stuart, H., Bernard, Y., 2000. Do corporate environmental standards create or destroy market value? Management Science, 46, 1059-1074.

Dyllick T, Hockerts K. 2002. Beyond the business case for corporate sustainability. Business Strategy and the Environment, 11, 130-141.

Edwards, M.G., 2009. An integrative metatheory for organizational learning and sustainability in turbulent times. The learning organization, 16(3), 189-207.

Elkington, J., 1994, Towards the sustainable corporation: Win-win-win business strategies for sustainable development. California Management Review, 36 (2), 90100 .

Epstein, M.J. and Roy, M.J., 2007. Implementing a Corporate Environmental Strategy: Establishing Coordination and Control within Multinational Companies. Business Strategy and the Environment, 16, 389-403.

Esty, D.C.,Winston,A.S., 2009. Green to Gold: How Smart Companies Use Environmental Strategy to Innovate, John Wiley and Sons. Available at: http://books.google.com/books?id=2NJ9fWqXLdwC\&pgis=1.

Ferdows, K., 1989. Mapping international factory networks, in Ferdows, K. (Ed.), 
Managing International Manufacturing, Elsevier, Amsterdam, 3-21.

Ferdows, K., 1997. Making the most of foreign factories. Harvard Business Review, March/April, 73-88

Frohlich, M.T., Westbrook, R., 2001. Arcs of integration: An international study of supply chain strategies. Journal of Operations Management 19 (2), 185-200.

Fusco, J.P. and Spring, M., 2003. Flexibility versus robust networks: the case of the Brazilian automotive sector. Integrated Manufacturing Systems, 14 (1), 26-35.

Gimenez, C., Sierra, V., Rodon, J., 2012. Sustainable operations: Their impact on the triple bottom line. International Journal of Production Economics, doi:10.1016/j.ijpe.2012.01.035

Govindarajulu, N., Daily, B.F., 2004. Motivating employees for environmental improvement, Industrial Management Data System, 104 (4), 36-372.

Gunasekaran, A., Spalanzani, A., 2011. Sustainability of manufacturing and services: Investigations for research and applications. International Journal of Production Economics, doi:10.1016/j.ijpe.2011.05.011

Hair, J.F., Black, W.C., Babin, B.J., Anderson, R.E., Tatham, R.L., 1998. Multivariate data analysis. Prentice hall Upper Saddle River, NJ.

Hart, S.L., 1995. A natural-resource-based view of the firm. Academy of Management Review, 20 (4), 986-1014.

Jahns, C., Hartmann, E., Bals, L., 2006. Offshoring: Dimensions and diffusion of a new business concept. Journal of Purchasing and Supply Management 12 (4), 218-231.

Jayaraman, V., Klassen, V.R., Linton, J.D., 2007. Supply chain management in a sustainable environment. Journal of Operation Management 25 (6), 1071-1074.

Kassinis, G., Vafeas, N., 2002. Stakeholder pressure and environmental performance. Academy of Management Journal, 49 (1), 145-159.

Kinkel, S., Maloca, S., 2009. Drivers and antecedents of manufacturing offshoring and backshoring--A German perspective. Journal of Purchasing and Supply Management 15 (3), 154-165.

Klassen, R.D., 2001. Plant-level environmental management orientation: the influence of management views and plant characteristics. Production and Operations Management, 10(3), 257-275.

Klassen, R.D., Vachon, S., 2003. Collaboration and evaluation in the supply chain: The impact on plant-level environmental investment. Production and Operations 
Management, 12(3), 336-352.

Klassen, R.D. and Whybark, D.C., 1999. The Impact of Environmental Technologies on Manufacturing Performance. Academy of Management Journal, 42 (6), 599-615.

Kleindorfer, P.R., Singhal, K., Van Wassenhove, L.N., 2005. Sustainable Operations Management. Production and Operations Management, 14 (4), 482-492.

Labuschagne, C., Brent, A.C., van Erck, R.P.G., 2005. Assessing the sustainability performances of industries. Journal of Cleaner Production, 13, 373-385.

Law, K.M.Y., Gunasekaran, A., 2009. A comparative study of schedule nervousness among high-tech manufacturers-across the straits. International Journal of Production Research, 1, 1-22.

Lee, K., Kim, J., 2009. Current status of CSR in the realm of supply management: the case of the Korean electronics industry. Supply Chain Management: An International Journal, 14 (2), 138-148.

Lee, S.Y. and Klassen, R.D., 2008. Drivers and enablers that foster environmental management capabilities in small- and medium-sized suppliers in supply chains. Production and Operations Management, 17 (6), 573-586.

Lee, S.Y. and Rhee, S., 2007. The change in corporate environmental strategies: A longitudinal empirical study. Management Decision, 45 (2), 196-216.

MacCarthy, B.L., Atthirawong, W., 2003. Factors affecting location decisions in international operations a Delphi study. International Journal of Operations \& Production Management, 23 (7/8), 794-819.

MacCarthy, B.L., Atthirawong, W., 2003. Factors affecting location decisions in international operations a Delphi study. International Journal of Operations \& Production Management 23 (7/8), 794-819.

Maignan, I., Ferrell, O.C., 2004. Corporate social responsibility and marketing: an integrative framework. Journal of the Academy of Marketing Science, 32 (1), 3-20.

Malhotra, M.K., Sharma, S., 2008. Measurement Equivalence Using Generalizability Theory: An Examination of Manufacturing Flexibility Dimensions. Decision Sciences 39 (4), 643-669.

Martin, G. and Beaumont, F., 1998. Diffusing 'best practice' in multinational firms: prospects, practice and contestation. The International Journal of Human Resource Management, 9 (4), 671-695 
McKenzie, S., 2004. Social Sustainability: Towards Some Definitions. Hawke Research Institute, University of South Australia. Magill.

Maritan, C.A., Brush, T.H. and Karnani, A.G., 2004. Plant roles and decision autonomy in multinational plant networks. Journal of Operations Management, 22, 489-503.

Melo, M.T., Nickel, S., Saldanha-da-Gama, F., 2009. Facility location and supply chain management - a review. European Journal of Operational Research, 196, 401-412.

Menard, S.W., 2002. Applied logistic regression analysis. Sage Publications, Inc.

Meijboom, B. and Voordijk, H., 2003. International operations and location decisions: a firm level approach. Tijdschrift voor Economische en Sociale Geografie, 94 (4), 463 76.

Meijboom, B. and Vos, B., 2004. Site competence dynamics in international manufacturing networks: instrument development and a test in Eastern European factories. Journal of Purchasing \& Supply Management, 10, 127-36.

Mohrman, S.A., Worley, C.G., 2010. The Organizational Sustainability Journey: Introduction to the Special Issue. Organizational Dynamics, 4 (39), 289-294.

Morrison-Saunders, A., Therivel, R., 2006. Sustainability integration and assessment. Journal of Environmental Assessment Policy and Management, 8 (3), 281-298.

Murray, J.Y., Kotabe, M., Wildt, A.R., 1995. Strategic and Financial Performance Implications of Global Sourcing Strategy: A Contingency Analysis. Journal of International Business Studies, 26 (1). 181-202.

Neter, J., Wasserman, W., Kutner, M.H., 1989. Applied linear regression models.

Pagell, M., Wu, Z., 2009. Building a more complete theory of sustainable supply chain management using case studies of 10 exemplars. Journal of Supply Chain Management, 45 (2), 37-55.

Pagell, M., Yang, C.L., Krumwiede, D.W., Sheu, C., 2004. Does the competitive environment influence the efficacy of investment in environmental management? Journal of Supply Chain Management, 40 (3), 30-39.

Peteraf, M.A., 1993. The Cornerstone of Competitive Advantage: A Resource-Based View. Strategic Management Journal, 14 (3), 179-191.

Pirsch, J., Gupta, S., Grau, S.L., 2007. A Framework for understanding corporate social responsibility programs as a continuum: an exploratory study. Journal of Business Ethics, 70, 125-140. 
Podsakoff, P.M., MacKenzie, S.B., Lee, J.Y., Podsakoff, N.P., 2003. Common method biases in behavioral research: A critical review of the literature and recommended remedies. Journal of applied psychology 88 (5), 879-903.

Porter, M.E., Kramer, M.R., 2006. The Link Between Competitive Advantage and Corporate Social Responsibility. Harvard Business Review, December, 1-24.

Porter, M.E., Van der Linde, C., 1995. Green and competitive: ending the stalemate. Harvard Business Review, 73(5), 120-34.

Pullman, M.E., Maloni, M.J., Carter, C.R., 2009. Food For Thought: Social Versus Environmental Sustainability Practices And Performance Outcomes. Journal of Supply

Rao, P., 2002. Greening the supply chain: a new initiative in South-East Asia. International Journal of Operations \& Production Management, 22(6), 632-655.

Ravi, V., Shankar, R., Tiwari, M.K., 2005. Analyzing alternatives in reverse logistics for end-of-life computers: ANP and balanced scorecard approach. Computers \& Industrial Engineering, 48, 327-356.

Roberts, R.W., 1992. Determinants of corporate social responsibility disclosure: an application of stakeholder theory. Accounting, Organizations \& Society, 17 (6), 595613.

Rothenberg, S., 2003. Knowledge content and worker participation in environmental managament at NUMMI. Journal of Management Studies, 40 (7), 1783-802.

Russo, M.V., 2009. Explaining the impact of ISO 14001 on emission performance: a Dynamic Capabilities Perspective on process learning. Business Strategy and Environment, 18, 307-319.

Russo, M.V., Fouts, P.A., 1997. A resource-based perspective on corporate environmental performance and profitability. Academy of Management Journal, 40 (3), 534-559.

Sarkis, J., 2003. A decision framework for green supply chain management. Journal of Cleaner Production, 11, 397-409.

Sarkis, J., Gonzalez-Torre, P., Adenso-Diaz, B., 2010. Stakeholder pressure and the adoption of environmental practices: The mediating effect of training. Journal of Operations Management, 28 (1), 163-174.

Seuring, S., Muller, M., 2008. From a literature review to a conceptual framework for sustainable supply chain management. Journal of Cleaner Production 16, 1699-1710. 
Shi, Y. and Gregory, M., 1998. International manufacturing networks - to develop global competitive capabilities. Journal of Operations Management, 16 (2), 195-214.

Sheu, J.-B., Chou, Y.H., Hu, C.C., 2005. An integrated logistics operational model for green-supply chain management. Transportation Research, Part E 41, 287-313.

Schmenner, R.W., 1979. Look beyond the obvious in plant location. Harvard Business Review, January/February, 126-32.

Schmenner, R.W., 1982. Multiplant manufacturing strategies among the Fortune 500. Journal of Operations Management, 2 (2), 77-86.

Stead, J.G. and Stead, W.E., 2009. Management for a small planet (3rd ed.), M.E. Sharpe, Armonk.

Steurer, R. and Konrad, A., 2009. Business-society relations in Central-Eastern and Western Europe: How those who lead in sustainability reporting bridge the gap in corporate (social) responsibility. Scandinavian Journal of Management, 25 (1), 23 36.

Teece, D.J., Pisano, G. and Shuen, A., 1997. Dynamic capabilities and strategic management. Strategic Management Journal, 18 (7), 509-533.

UNCTAD, 2010. World investment report. New York/Geneva: United Nations.

Vachon, S., 2007. Green supply chain practices and the selection of environmental technologies. International Journal of Production Research, 45 (18-19), 4357-4379.

Vachon, S., Mao, Z., 2006. Extending green practices across the supply chain: the impact of upstream and downstream integration. International Journal of Operations \& Production Management, 25 (7), 795-821.

Vachon, S., Mao, Z., 2008. Linking supply chain strength to sustainable development: a country-level analysis. Journal of Cleaner Production, 16, 1552-1560.

Van Bommel, H.W.M, 2011. A conceptual framework for analyzing sustainability strategies in industrial supply networks from an innovation perspective. Journal of Cleaner Production, 19, 895-904.

Van de Vijver, F.J.R., Leung, K., 1997. Methods and data analysis for cross-cultural research. Sage Publications, Inc.

van Kleef, J.A.G. and Roome, N.J., 2007. Developing capabilities and competence for sustainable business management as innovation: a research agenda. Journal of Cleaner Production, 15, 38-51. 
Vereecke, A., Van Dierdonck, R., 2002. The strategic role of the plant: testing Ferdows's model. International Journal of Operations \& Production Management 22 $(5 / 6), 492-514$.

Voss, C., Blackmon, K., 1998. Differences in manufacturing strategy decisions between Japanese and Western manufacturing plants: the role of strategic time orientation. Journal of Operations Management 16 (2-3), 147-158.

Zairi, M. and Peters, J., 2002. The impact of social responsibility on business performance, Managerial Auditing Journal, 17 (4), 174-178.

Zhu, Q. and J. Sarkis, 2004. Relationships Between Operational Practices and Performance Among Early Adopters of Green Supply Chain Management Practices in Chinese Manufacturing Enterprises. Journal of Operations Management, 22, 265 289.

Zhu, Q., Sarkis, J., Geng, Y., 2005. Green supply chain management in China: pressures, practices and performance. International Journal of Operations \& Production Management, 25 (5), 449-468.

Zhu, Q., Sarkis, J., Lai, K.H., 2007. Initiatives and outcomes of green supply chain management implementation by Chinese manufacturers. Journal of Environmental Management, 85, 179-189.

Zhu, Q.H., Cote, R., 2004. Integrating green supply chain management into an embryonic eco-industrial development: a case study of the Guitang Group. Journal of Cleaner Production, 12 (8-10), 1025-1035. 


\section{Tables}

Table 1a-Descriptive statistics in terms of country and size

\begin{tabular}{|c|c|c|c|c|c|c|c|c|}
\hline Country & $\mathbf{N}$ & $\%$ & Country & $\mathbf{N}$ & $\%$ & Size* & $\mathbf{N}$ & $\%$ \\
\hline Belgium & 23 & 4.3 & Korea & 32 & 6.0 & Small & 276 & 51.7 \\
\hline Brazil & 30 & 5.6 & Mexico & 11 & 2.1 & Medium & 93 & 17.4 \\
\hline Canada & 16 & 3.0 & The Netherlands & 40 & 7.5 & Large & 165 & 30.9 \\
\hline China & 39 & 7.3 & Portugal & 8 & 1.5 & Total & 534 & 100.0 \\
\hline Denmark & 14 & 2.6 & Romania & 23 & 4.3 & & & \\
\hline Estonia & 22 & 4.1 & Spain & 35 & 6.6 & & & \\
\hline Germany & 34 & 6.4 & Switzerland & 26 & 4.9 & & & \\
\hline Hungary & 50 & 9.4 & Taiwan & 27 & 5.1 & & & \\
\hline Ireland & 5 & .9 & UK & 10 & 1.9 & & & \\
\hline Italy & 41 & 7.7 & USA & 31 & 5.8 & & & \\
\hline Japan & 17 & 3.2 & Total & 534 & 100.0 & & & \\
\hline
\end{tabular}

*Size: Small: less than 250 employees. Medium: 251-500 employees. Large: over 501 employees

Table $1 b$ - Descriptive statistics in terms of industrial sector (ISIC codes)

\begin{tabular}{ccc|ccc}
\hline ISIC Code & Frequency & \% & ISIC Code & Frequency & \% \\
\hline 28 & 184 & 34.5 & 33 & 28 & 5.2 \\
29 & 141 & 26.4 & 34 & 42 & 7.9 \\
30 & 8 & 1.5 & 35 & 22 & 4.1 \\
\cline { 3 - 6 } 31 & 76 & 14.2 & Total & $\mathbf{5 3 4}$ & $\mathbf{1 0 0 . 0}$ \\
\cline { 3 - 6 } 32 & 33 & 6.2 & & &
\end{tabular}

ISIC Code (Rev. 3.1): 28: Manufacture of fabricated metal products, except machinery and equipment; 29: Manufacture of machinery and equipment not classified elsewhere; 30: Manufacture of office, accounting, and computing machinery; 31 : Manufacture of electrical machinery and apparatus not classified elsewhere; 32 : Manufacture of radio, television, and communication equipment and apparatus; 33: Manufacture of medical, precision, and optical instruments, watches and clocks; 34 : Manufacture of motor vehicles, trailers, and semitrailers; 35: Manufacture of other transport equipment.

Table 2 - Sustainability related programs included in the analysis

\begin{tabular}{|l|l|}
\hline \multicolumn{1}{|c|}{ Literature classification } & \multicolumn{1}{|c|}{ IMSS questionnaire items } \\
\hline $\begin{array}{l}\text { Environmental process } \\
\text { management (Daily \& } \\
\text { Huang, 2001) }\end{array}$ & $\begin{array}{l}\text { Improving environmental performance of processes and products (e.g., } \\
\text { environmental management system, Life-Cycle Analysis, Design for } \\
\text { Environment, environmental certifications) }\end{array}$ \\
\hline $\begin{array}{l}\text { Environmental-friendly } \\
\text { product design ) (Zhu \& } \\
\text { Sarkis, 2004) }\end{array}$ & $\begin{array}{l}\text { Improving the environmental impact of products by appropriate design } \\
\text { measures, e.g., design to recycle }\end{array}$ \\
\hline $\begin{array}{l}\text { Environmental logistics } \\
\text { policy (Ciliberti et al., } \\
2008)\end{array}$ & $\begin{array}{l}\text { Improving the environmental impact generated by transportation of } \\
\text { materials/products and outsourcing of process steps }\end{array}$ \\
\hline $\begin{array}{l}\text { Internal social programs } \\
\text { Zairi \& Peters, 2002) }\end{array}$ & $\begin{array}{l}\text { Enhancing corporate reputation through firm's direct contribution and } \\
\text { other campaigns (e.g., employment, safety, work conditions, corporate } \\
\text { social activities, support community projects) }\end{array}$ \\
\hline $\begin{array}{l}\text { Supply chain social } \\
\text { programs (Carter, 2005) }\end{array}$ & $\begin{array}{l}\text { Monitoring corporate social responsibility of partners along the supply } \\
\text { chain (e.g., labor conditions) }\end{array}$ \\
\hline
\end{tabular}


Table 3 - Distribution of the sample on competence and home country

\begin{tabular}{lccccccc}
\hline \multicolumn{7}{c}{ Competence Groups (CG) } & \multirow{2}{*}{ Total } \\
\cline { 1 - 5 } & & 1 & 2 & 3 & 4 & 5 & \\
\hline Home country & No & $58(11 \%)$ & $57(11 \%)$ & $25(5 \%)$ & $18(3 \%)$ & $36(7 \%)$ & $194(36 \%)$ \\
& Yes & $101(19 \%)$ & $96(18 \%)$ & $43(8 \%)$ & $46(9 \%)$ & $54(10 \%)$ & $340(64 \%)$ \\
\hline Total & & $159(30 \%)$ & $153(29 \%)$ & $68(13 \%)$ & $64(12 \%)$ & $90(17 \%)$ & $534(100 \%)$ \\
\hline
\end{tabular}

Table 4 - Average values of sustainability programs and performance for the different levels of site competence (in bold groups that are significantly different from the group before).

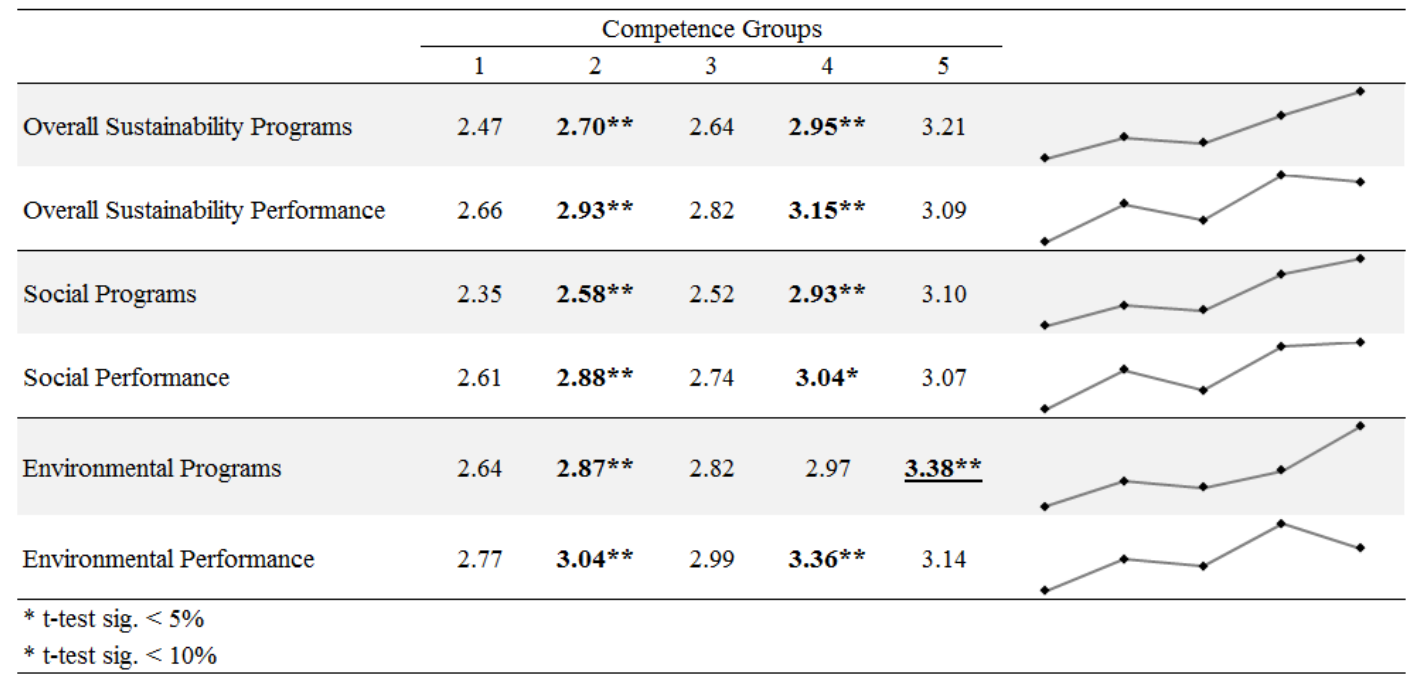

Table 5 - Mean values between companies in high and low competence groups

\begin{tabular}{|c|c|c|c|}
\hline & CompetenceHL & Mean & t-test sig \\
\hline \multirow[t]{2}{*}{ Overall Sustainability Programs } & Low & 2.59 & \multirow[t]{2}{*}{0.000} \\
\hline & High & 3.12 & \\
\hline \multirow{2}{*}{$\begin{array}{l}\text { Overall Sustainability } \\
\text { Performance }\end{array}$} & Low & 2.79 & \multirow[t]{2}{*}{0.000} \\
\hline & High & 3.12 & \\
\hline \multirow[t]{2}{*}{ Social Programs } & Low & 2.47 & \multirow[t]{2}{*}{0.000} \\
\hline & High & 3.06 & \\
\hline \multirow[t]{2}{*}{ Social Performance } & Low & 2.73 & \multirow[t]{2}{*}{0.000} \\
\hline & High & 3.06 & \\
\hline \multirow[t]{2}{*}{ Environmental Programs } & Low & 2.76 & \multirow[t]{2}{*}{0.000} \\
\hline & High & 3.22 & \\
\hline \multirow[t]{2}{*}{ Environmental Performance } & Low & 2.92 & \multirow[t]{2}{*}{0.000} \\
\hline & High & 3.25 & \\
\hline
\end{tabular}


Table 6 - Step 1 of the mediation: testing the relationship between site competence and the sustainability programs

\begin{tabular}{|c|c|c|c|c|c|c|}
\hline & \multicolumn{2}{|c|}{$\begin{array}{c}\text { Overall } \\
\text { (Dep. Overall } \\
\text { Sustainability } \\
\text { Programs) } \\
\end{array}$} & \multicolumn{2}{|c|}{$\begin{array}{c}\text { Social } \\
\text { (Dep. Social } \\
\text { Programs) } \\
\end{array}$} & \multicolumn{2}{|c|}{$\begin{array}{c}\text { Environmental } \\
\text { (Dep. Environmental } \\
\text { Programs) }\end{array}$} \\
\hline & $\begin{array}{l}\text { Std. } \\
\text { Beta }\end{array}$ & Sig. & $\begin{array}{l}\text { Std. } \\
\text { Beta }\end{array}$ & Sig. & $\begin{array}{l}\text { Std. } \\
\text { Beta }\end{array}$ & Sig. \\
\hline (Constant) & & .039 & & .129 & & .023 \\
\hline GNI (country) & -.205 & .000 & -.216 & .000 & -.218 & .000 \\
\hline Strategic orientation (overall/social/env.) & .553 & .000 & .484 & .000 & .384 & .000 \\
\hline Size $(\ln )$ & .172 & .000 & .162 & .000 & .196 & .000 \\
\hline Home country & -.047 & .141 & -.055 & .112 & -.039 & .300 \\
\hline CompetenceHL & .126 & .000 & .150 & .000 & .116 & .002 \\
\hline $\mathrm{R}^{2}$ & .51 & & .43 & & .33 & \\
\hline $\mathrm{N}$ & 534 & & 534 & & 534 & \\
\hline
\end{tabular}

Table 7 -Step 2 and 3 of the mediation: testing the direct relationship between site competence and the sustainability performance without (model 1) and with the mediator variable (model 2)

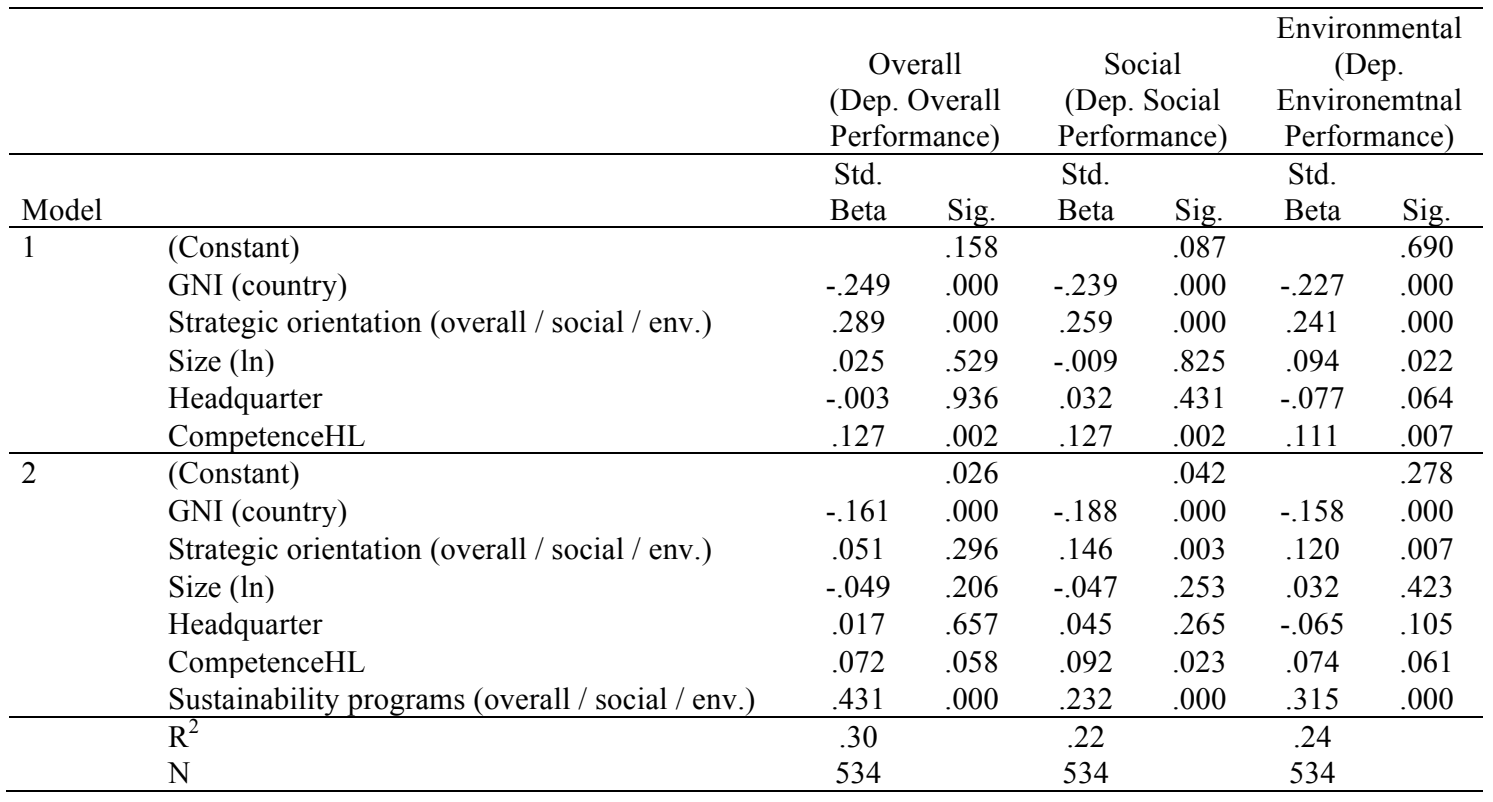


Table A.1 - Results of the factor analysis on sustainability items

\begin{tabular}{llcc}
\hline & \multicolumn{3}{c}{ Factor } \\
& $\begin{array}{c}\text { Overall } \\
\text { Sustainability } \\
\text { Performance }\end{array}$ & $\begin{array}{c}\text { Overall } \\
\text { Sustainability } \\
\text { Programs }\end{array}$ & $\begin{array}{c}\text { Overall } \\
\text { Sustainability } \\
\text { Orientation }\end{array}$ \\
\hline $\begin{array}{l}\text { Environmental products and processes } \\
\text { (orientation) }\end{array}$ & & .855 \\
Committed social responsibility (orientation) & & & .843 \\
\hline Corporate social responsibility (program) & .685 & \\
Corporate reputation (program) & .632 & \\
Environmental performance (program) & .804 & & \\
Environmental process management (program) & .783 & & \\
Environmental logistics policy (program) & .700 & .834 & \\
\hline Employee satisfaction (performance) & & .707 & .826 \\
Environmental performance (performance) & & .863 & \\
Social reputation (performance) & & & \\
\hline Cronbach Alpha & & & \\
\hline Explained variance: $71 \%$; Eigenvalues $>0.8$ & & & \\
\hline
\end{tabular}

Table A.2 - Descriptive statistics of the calculated factors

\begin{tabular}{lcccc}
\hline & Minimum & Maximum & Mean & $\begin{array}{c}\text { Std. } \\
\text { Deviation }\end{array}$ \\
\hline Overall Sustainability Orientation & 1 & 5 & 3.03 & 1.11 \\
Overall Sustainability Programs & 1 & 5 & 2.74 & 0.95 \\
Overall Sustainability Performance & 1 & 5 & 2.89 & 0.80 \\
Social Sustainability Orientation & 1 & 5 & 2.93 & 1.25 \\
Social Programs & 1 & 5 & 2.64 & 1.05 \\
Social Performance & 1 & 5 & 2.83 & 0.86 \\
Environmental Sustainability Orientation & 1 & 5 & 3.13 & 1.16 \\
Environmental Programs & 1 & 5 & 2.90 & 1.00 \\
Environmental Performance & 1 & 5 & 3.01 & 0.92 \\
\hline
\end{tabular}


Table A.3 - Correlation table of the calculated factors

\begin{tabular}{|c|c|c|c|c|c|c|c|c|c|c|}
\hline & & 1 & 2 & 3 & 4 & 5 & 6 & 7 & 8 & 9 \\
\hline $\begin{array}{l}\text { Overall sustainability } \\
\text { orientation }\end{array}$ & 1 & 1 & $.663 * *$ & $.382 * *$ & $.931 * *$ & $.636^{* *}$ & $.335^{* *}$ & $.921 * *$ & $.574 * *$ & $.370 * *$ \\
\hline $\begin{array}{l}\text { Overall Sustainability } \\
\text { Programs }\end{array}$ & 2 & $.663 * *$ & 1 & $.520 * *$ & $.631 * *$ & $.952 * *$ & $.451 * *$ & $.595 * *$ & $.877 * *$ & $.511 * *$ \\
\hline $\begin{array}{l}\text { Overall Sustainability } \\
\text { Performance }\end{array}$ & 3 & $.382 * *$ & $.520 * *$ & 1 & $.378 * *$ & $.465 * *$ & $.953 * *$ & $.329 * *$ & $.502 * *$ & $.824 * *$ \\
\hline $\begin{array}{l}\text { Social sustainability } \\
\text { orientation }\end{array}$ & 4 & $.931 * *$ & $.631 * *$ & $.378 * *$ & 1 & $.591 * *$ & $.338 * *$ & $.715^{* *}$ & $.570 * *$ & $.353 * *$ \\
\hline Social Programs & 5 & $.636^{* *}$ & $.952 * *$ & $.465^{* *}$ & $.591 * *$ & 1 & $.386^{* *}$ & $.586^{* *}$ & $.687^{* *}$ & $.490 * *$ \\
\hline Social Performance & 6 & $.335^{* *}$ & $.451 * *$ & $.953 * *$ & $.338 * *$ & $.386 * *$ & 1 & $.281 * *$ & $.462 * *$ & $.613^{* *}$ \\
\hline $\begin{array}{l}\text { Environmental } \\
\text { sustainability } \\
\text { orientation }\end{array}$ & 7 & $.921^{* *}$ & $.595 * *$ & $.329 * *$ & $.715^{* *}$ & $.586^{* *}$ & $.281 * *$ & 1 & $.490 * *$ & $.331 * *$ \\
\hline $\begin{array}{l}\text { Environmental } \\
\text { Programs }\end{array}$ & 8 & $.574 * *$ & $.877 * *$ & $.502 * *$ & $.570 * *$ & $.687 * *$ & $.462 * *$ & $.490 * *$ & 1 & $.442 * *$ \\
\hline $\begin{array}{l}\text { Environmental } \\
\text { Performance }\end{array}$ & 9 & $.370 * *$ & $.511 * *$ & $.824 * *$ & $.353 * *$ & $.490 * *$ & $.613 * *$ & $.331 * *$ & $.442 * *$ & 1 \\
\hline
\end{tabular}


Figure 1 - General research model

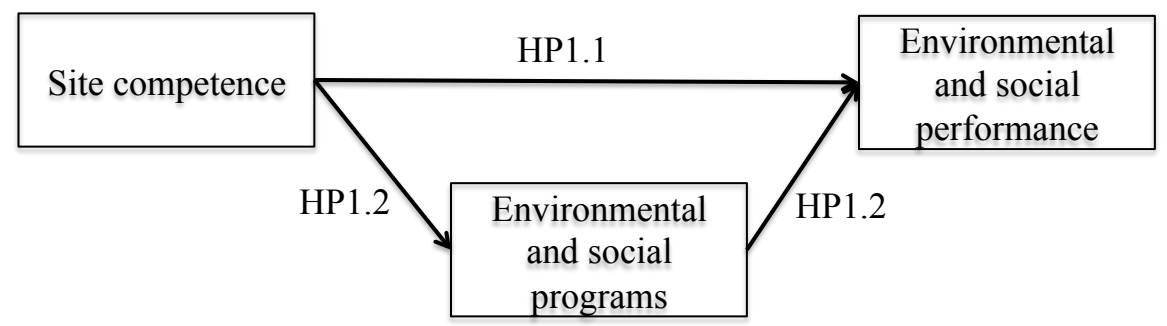

